\title{
Expression of p16, p53, CD24, EpCAM and Calretinin in Serous Borderline Tumors of the Ovary
}

\section{Overin Seröz Borderline Tümör Tiplerinde p16, p53, CD24, EpCAM ve Kalretinin Ekspresyonu}

\author{
IşıI YILDIZ AKTAŞ, Meral BUĞDAYCI, AIp USUBÜTÜN \\ Department of Pathology, Hacettepe University, Faculty of Medicine, ANKARA, TURKEY
}

\begin{abstract}
Objective: According to the widely accepted pathway, a serous borderline tumor becomes invasive either by progressing into a noninvasive micropapillary tumor or directly through microinvasion. Our objective was to investigate the role of serous borderline tumors and their accompanying extraovarian lesions in pathogenesis of serous ovarian cancer using immunohistochemistry as a tool.
\end{abstract}

Material and Method: An immunohistochemical panel of p16, p53, CD24, EpCAM and calretinin was applied to cutting edge matrix assembly-like tissue arrays of 46 cases consisting of typical, focal micropapillary, micropapillary, microinvasive, cystadenoma, and low-grade carcinoma cases. These tissue arrays are better choices than conventional tissue arrays to examine thin walled and heterogenous neoplasia like serous borderline tumors as they facilitate the analysis with linear sections rather than a core.

Results: For two tumor supressor gene markers; no diffuse and strong expression of $\mathrm{p} 53$, and strong and patchy/heterogenous expression of p16 were detected in all cases. Focal and strong calretinin expression was detected in micropapillary tumors while expression of EpCAM was lost in the same areas. Strong cytoplasmic CD24 expression was detected in cases with peritoneal implants, favoring the theory that change of expression localization of cell adhesion molecules is in accordance with phenotypical changes and tumor progresssion. Furthermore, circumfrential membranous and cytoplasmic expression of CD24 and EpCAM was detected in neoplastic cells in lymph nodes and microinvasion areas.

Conclusion: Our results show that different levels of serous ovarian tumor progression are accompanied by changes in the immunohistochemical expression pattern of EpCAM, CD24, and calretinin.

Key Words: Ovary, Tumor, p16 protein, p53 antigen, CD24 antigen, EpCAM protein, Calretinin

\begin{abstract}
ÖZ
Amaç: Over kanserinin yaygın olarak kabul gören patogenez modeline gore bir seröz borderline tümör invaziv olmadan önce, noninvaziv mikropapiller aşamaya geçer veya tipik bir seröz borderline tümör zemininde mikroinvazyon yaparak invaziv aşamaya geçer. $\mathrm{Bu}$ çalışmanın amacı seröz borderline tümörler ve over dışı lezyonlarının seröz over kanseri patogenezindeki rolünü immunohistokimyasal bir panelle incelemektir.
\end{abstract}

Gereç ve Yöntem: Tipik, fokal mikropapiller, mikropapiller, mikroinvaziv, kistadenom ve düşük dereceli karsinom alanları içeren 46 olguluk seröz borderline tümör grubuna p16, p53, CD24, EpCAM ve kalretininden oluşan immünohistokimyasal bir panel uygulandı. $\mathrm{Bu}$ panelin degerlendirilmesi icin seröz borderline tümörler gibi kistik/ince duvarlı ve heterojen neoplazileri incelerken lineer bir kesite bakma imkanı vermesi nedeni ile daha avantajlı olan "cutting edge" matriks-benzeri doku arrayleri hazırlandı.

Bulgular: Tümör supresörgen grubunda değerlendirilen iki işaretleyici ile diffüz, kuvvetli p53 ekspresyonu hiçbir olguda saptanmaz iken,olguların tümünde p16 ile kuvvetli, heterojen ekspresyon izlendi. Kalretinin ile mikropapiller tümörlerde fokal kuvvetli ekspresyon izlenirken, EpCAM ile aynı alanlarda ekspresyon kaybı saptandı. Hücre adezyon moleküllerinin ekspresyon lokalizasyonlarındaki değişikliklerin fenotipte değişme ve tümör progresyonu ile ilişkili olabileceğini destekler şekilde, peritoneal implantların saptandığı olgularda sitoplazmik ve kuvvetli CD24 ekspresyonu görüldü. Lenf nodu tutulumu ve mikroinvazyon alanlarında çembersel membranöz ve sitoplazmik CD24 ve EpCAM ekspresyonu görüldü.

Sonuç: Bulgular, seröz over tümörü progresyonunun farklı aşamalarına EpCAM, CD24, ve kalretinin immünohistokimyasal ekspresyon paternindeki değişikliklerin eşlik edebildiğini göstermektedir.

Anahtar Sözcükler: Over tümörleri, p16 proteini, p53 antijeni, CD24 antijeni, EpCAM proteini, Calretinin
(Turk Patoloji Derg 2012, 28:220-230)

Received : 08.04.2012 Accepted : 13.08 .2012
Correspondence: Alp USUBÜTÜN

Department of Pathology, Hacettepe University, Faculty of Medicine, ANKARA, TURKEY

E-mail: alpusubutun@yahoo.com Phone: +90 5365147717 


\section{INTRODUCTION}

Low-grade serous carcinomas of the ovary evolve from adenofibromas or borderline tumors following Type I pathway through a slow step-wise process. A serous borderline tumor (SBT) progresses either to noninvasive micropapillary or microinvasive stage before becoming invasive. On the other hand, high-grade serous carcinomas develop rapidly without a definite precursor lesion through Type II pathway. Rare high-grade serous carcinomas arising through the Type I pathway have been reported (1-3).

In this study, immunohistochemical expression of p16, p53, CD24, EpCAM and calretinin, markers with defined roles in tumor suppression, cell adhesion, therapy and differentiation, respectively, have been investigated in a group of SBTs (4-7).

This study is an initiative to understand the role of SBTs and their accompanying extraovarian lesions in histopathological progression of serous ovarian cancer considering that effective prevention and screening methods are still lacking for ovarian cancer.

\section{MATERIAL and METHODS}

Case Selection: Cases diagnosed as low grade serous carcinoma or SBT of the ovary over 12 years at our pathology department were re-evaluated by 2 pathologists with 5 to $19 \mathrm{H} \& \mathrm{E}$ slides of neoplastic ovarian tissue from each case. The study group of 46 cases were composed of cases that were diagnosed as serous cystadenoma with borderline component $(n=2)$, typical SBT $(n=22)$, micropapillary SBT $(\mathrm{n}=3)$, focal micropapillary SBT (SBT with micropapillary areas) $(n=11)$, microinvasive SBT $(n=6)$ and low grade serous carcinoma $(n=2)$. Demonstrative H\&E slides ( 1 to 5 slides for each case) were selected and paraffin blocks were pulled from the archives. All the cases registered in the pathology files with accompying features to borderline morphology and 22 classical serous borderline tumors were randomly selected. Accompanying extraovarian lesions (peritoneal implant, lymph node involvement or endosalpingiosis) were noted when present. This study was proceeded by permission from the Ethical Commission of our institution (FON 05/41-22).

Construction of CEMA-like Tissue Blocks: Tissue blocks were prepared using the principle of "Cutting Edge Matrix Assembly (CEMA)" method introduced by Rui and LeBaron (8-9). Common pathology laboratory equipment can be used to generate a CEMA array without additional instruments (needle, machine, receiver paraffin block) needed for tissue microarray technique (TMA) (Figure 1A-
D). Moreover, a feature of CEMA that core based sample arrays does not provide is the ability to array samples that are thin walled and heterogenous like SBTs due to the nature of the neoplasia. Thirteen new blocks were prepared by this method. The samples ( 1 to 5 from each case) were taken from extraovarian lesions whenever possible as well as from the neoplastic ovarian tissue. Once the CEMA array block had been constructed, repeated microtome sectioning allowed production of microarray copies for serial analyses of stains. The array block was sectioned transversely using a microtome to yield micrometer-thin array sections. 6 sections from each of the 13 blocks were taken: 1 for $\mathrm{H} \& \mathrm{E}$ and 5 for immunohistochemical staining.

Histopathologic diagnostic criteria: The histopathologic criteria for each diagnosis according to the WHO (World Health Organization) classification is as follows (10): Serous cystadenoma with borderline component: Serous cystadenoma cases containing stratified epithelial proliferation with mitotic activity and nuclear atypia in less than $10 \%$ of the area. Typical SBT: Cases containing intracystic and exophytic, stratified epithelial proliferation in more than $10 \%$ of the area, with hierarchically branched papillas and without stromal invasion. The cells lining the papilla may contain mitotic activity and nuclear atypia. Micropapillary SBT: Cases containing intracystic and exophytic, stratified epithelial proliferation in at least one focus in a $5 \mathrm{~mm}$ area continuously, with nonhierarchically branched, hair-like, regularly contoured micropapillas and without stromal invasion. Focal micropapillary SBT (SBT with micropapillary areas): The cases in which micropapillary SBT features are exhibited in an area less than $5 \mathrm{~mm}$. Microinvasive SBT: SBT cases containing single tumor cells or cell groups in single or multiple foci in stroma. Microinvasion extent is not over $3-5 \mathrm{~mm} / 10 \mathrm{~mm}^{2}$ in a single focus. Low grade serous carcinoma: Architecturally complex cases where stromal invasion extent is over microinvasion and is infiltrative with cytologic atypia. Endosalpingiosis: A lesion located on periton, pelvic organ surfaces or in pelvic lymph nodes, composed of one or more glands with tubal type, flattened, cuboidal or columnar multilayered epithelial lining of serous and mostly ciliated cells with minimal cytologic atypia. Noninvasive peritoneal implant: Papillary or glandular epithelial proliferation, located on serosal surfaces or septae between fat globules, composed of cells with large, eosinophilic cytoplasm. The border between the implant and underlying benign tissue should be sharp and there should be no invasion to the underlying tissue.

Immunohistochemistry: Formalin-fixed, paraffinembedded tissues were dewaxed and gradually rehydrated 

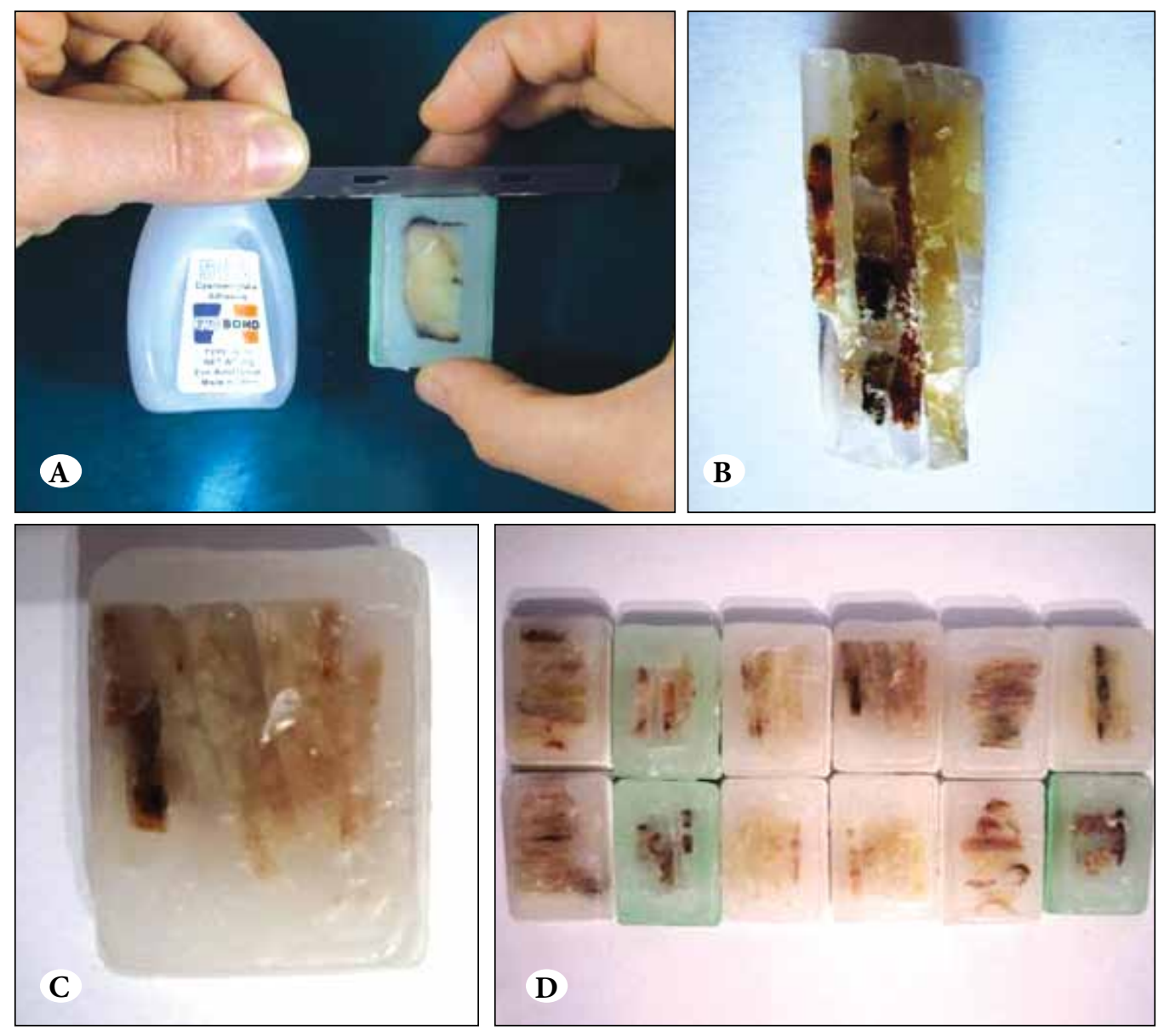

Figure 1: "Cutting Edge Matrix Assembly" (CEMA) method. (A) The samples were prepared by cutting the blocks manually with a microtome knive.

(B) Block were constructed by using a cyanoacrylic glue. $(C, D)$ The blocks are ready to use.

with alcohol. Endogenous peroxidase activity was blocked by $3 \%$ hydrogen peroxidase-metanol solution. Antigen retrieval for p16, p53,WT-1, c-erbB-2 and calretinin was achieved by pressure-cooking in citrate buffer $(0.01$ $\mathrm{M}, \mathrm{pH}=6$ ) for 20 minutes. Slides were pre-treated with tripsin for EpCAM and no pre-treatment for CD24. Immunohistochemical stainings were performed using LSAB (labeled streptavidin-biotin; DAKO) methods. The antibodies, their manufacturer and dilutions are as follows: p16 (LabVision; dilution 1:50), p53 (Immuno Vision; dilution 1:100), CD24 (Neomarkers; dilution 1:100), EpCAM (Neomarkers; dilution 1:100), Calretinin (Biogenex; dilution 1:50). Slides were subsequently incubated with the antibodies for 30 minutes. DAB (Diaminobenzidine) was used as a chromogen.

Evaluation: In each case, the localization, distribution, proportion and intensity of the immunohistochemical staining of the markers were evaluated. Staining localization categories for membranous antigens, CD24 and EpCAM, were circumferential, apical and basolateral whereas the categories for nuclear antigens, p16, p53 and calretinin, were nuclear and nuclear and cytoplasmic. Staining distribution was classified as diffuse and patchy. Staining ratio was evaluated quantitatively as follows: 0 (negative), $1+$ (staining in less than $10 \%$ of the neoplastic cells), $2+$ (staining in 10-50\% of the neoplastic cells) and $3+$ (staining in over $50 \%$ of the neoplastic cells). Staining intensity was evaluated semi-quantitatively as follows: 0 (negative), $1+$ (weak), and 2+ (strong).

Statistical Analysis: SPSS 11.0 was used for statistical analysis. Categorical variables, such as the staining distribution, staining ratio and staining intensity were summarized as frequency and percent. The Chi-square analysis was used to assess the relationship between categorical variables. Spearman's rho, Kendall's-tau-b and Pearson's correlation coefficient were used to calculate the correlation between different markers. P values $<0.05$ were considered statistically significant.

\section{RESULTS}

The distribution of p16, p53, CD24 and EpCAM expression as number and percentage of cases according to tumor types and extraovarian lesions is summarized on Table I. 


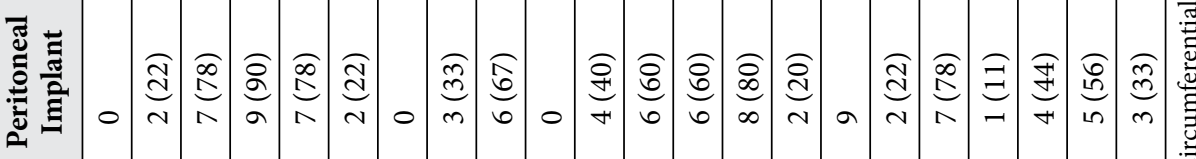

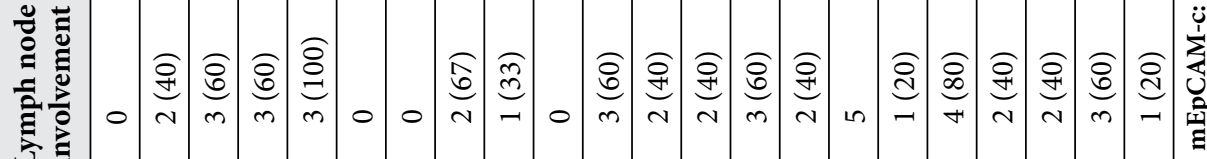

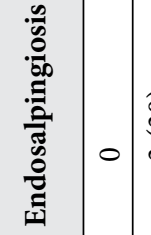

วิ)

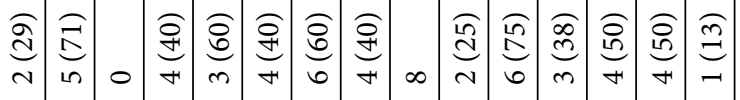

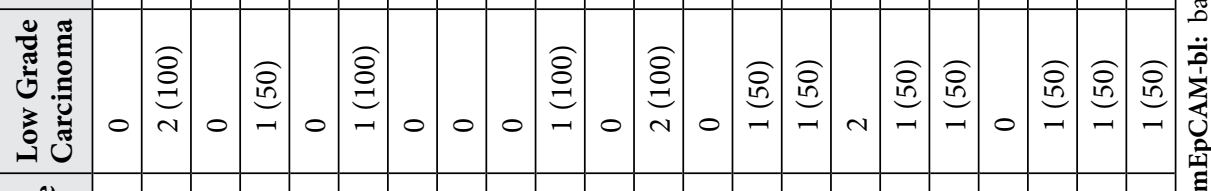

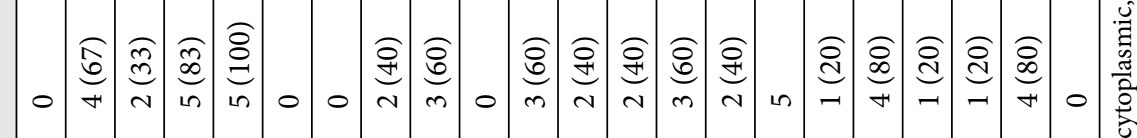

总

चृ

¿ี

害

क तु

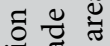

के

䒺远

$\sum$ ॠ

ठㅇ

语范

สี

茟 के

ชิ

กำ

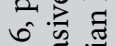

๑

फे

을 블

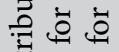

Е ए

(50. 50

F. \&

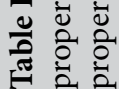

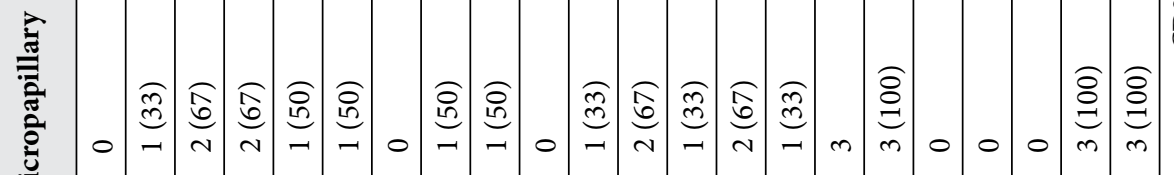

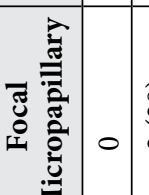

จิ

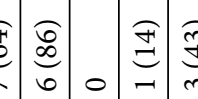

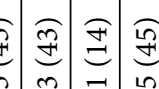

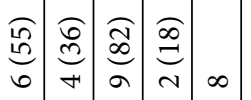

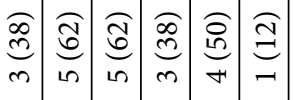

चै

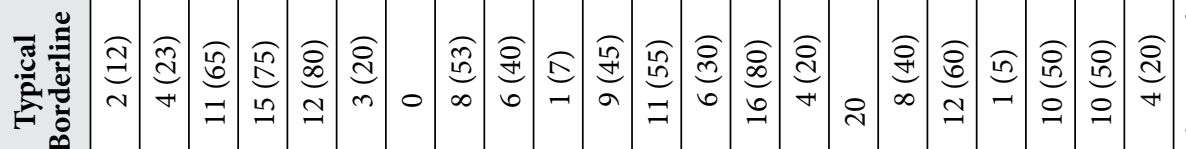

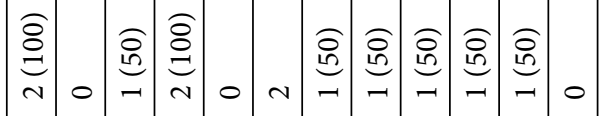

華苍

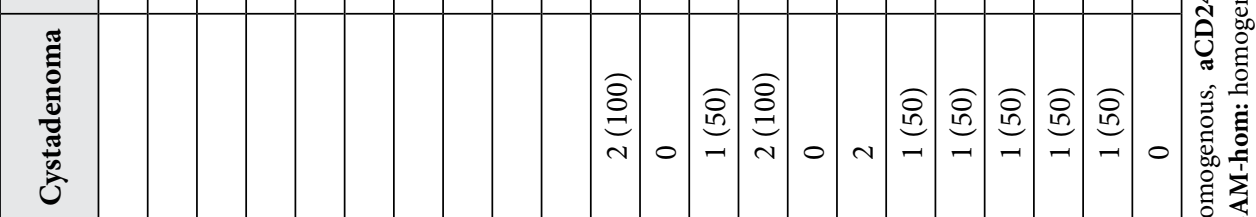

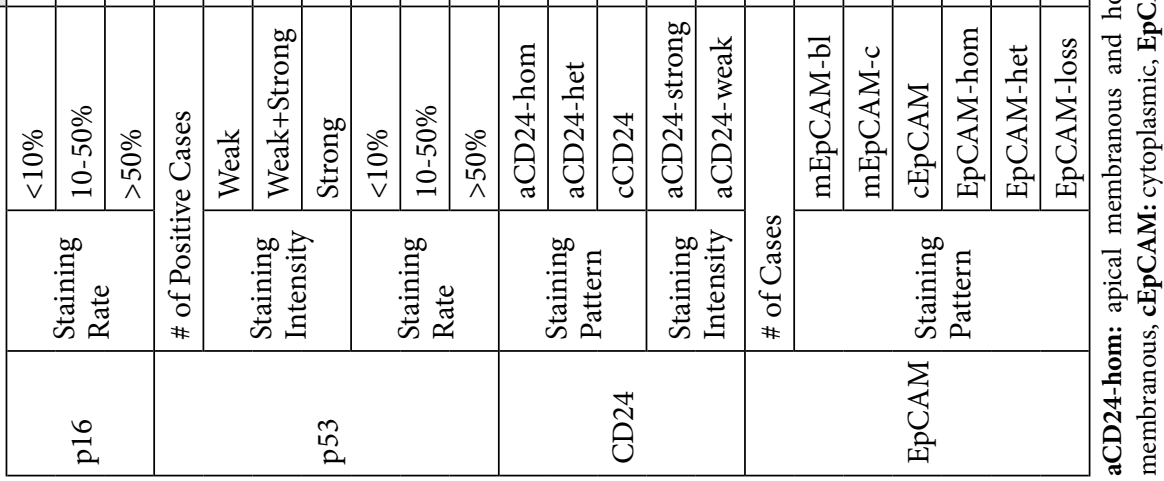


Expression of p16 and p53: p16 staining was strong and patchy in all (38/38) cases (Figure 2A). The pattern of staining was nuclear and cytoplasmic in 37 (97.4\%) cases. Diffuse and strong positivity in stromal cells in the neoplastic areas was noticed (Figure 2B). The neoplastic cells in the lymph nodes and microinvasion areas also showed strong, patchy and nuclear and cytoplasmic staining (Figure 2C). In low grade carcinoma cases, p16 expression was diffuse (Figure 2D). P53 expression was present in $68 \%(30 / 44)$ of the cases. No p53 expression was detected in borderline tumors with cystadenoma component. Only $10 \%(3 / 30)$ of the $\mathrm{p} 53$ positive cases had a staining ratio of over $50 \%$. Furthermore, the intensity of p53 staining was weak in $80 \%(24 / 30)$ of the positive cases. Neoplastic cells in the lymph node were observed to express p53 in a higher ratio and intensity (Figure $3 \mathrm{~A}, \mathrm{~B}) .1$ case that showed diffuse
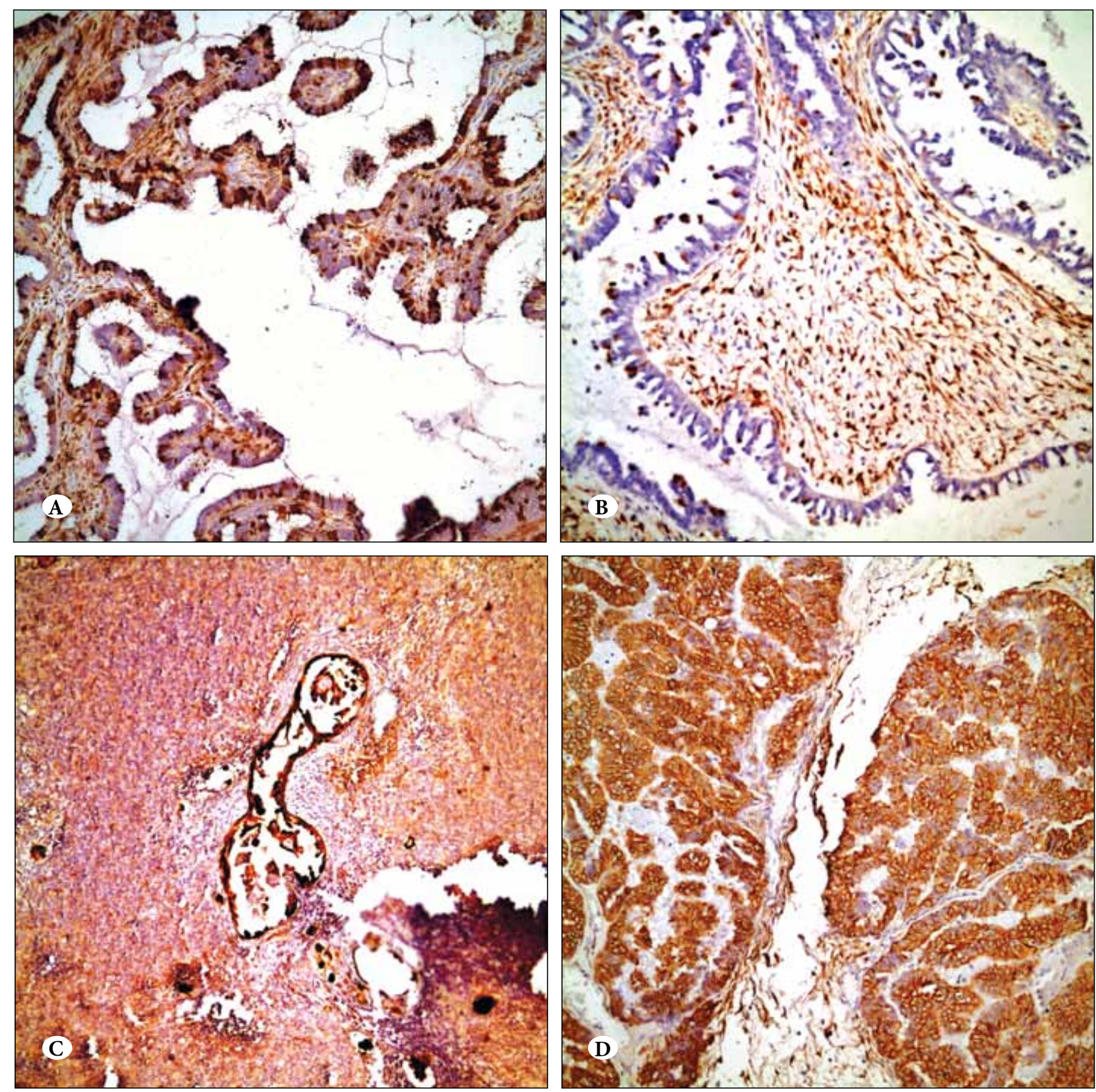

Figure 2: p16 expression intensity and pattern. (A) Strong and heterogenous/patchy expression in all cases (x400). Expression in (B) stromal cells (x200), (C) involved lymph nodes (x200). (D) Homogenous/diffuse expression in low grade serous carcinoma (x400). 

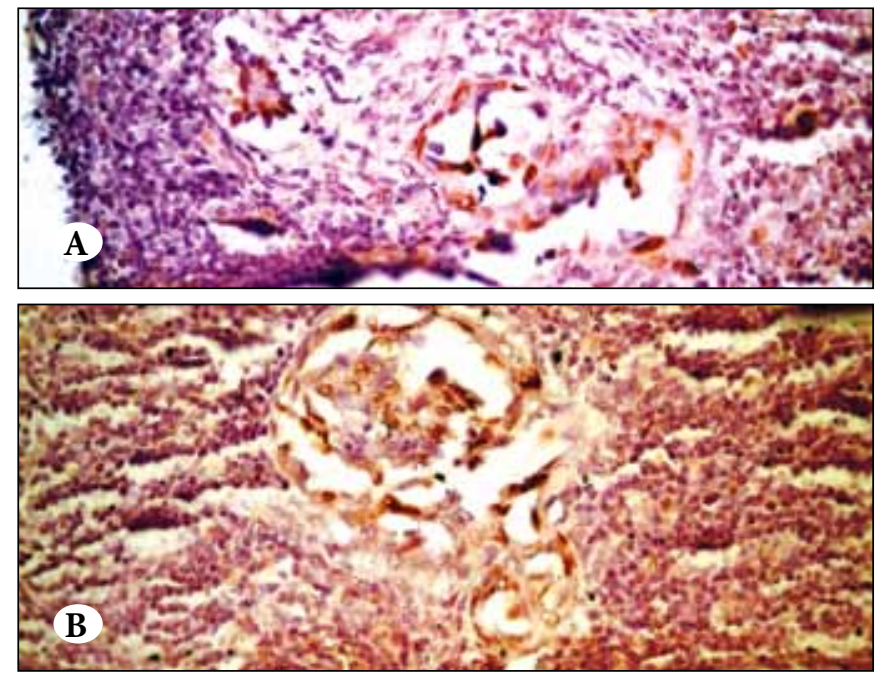

Figure 3A, B: p53 expression in involved lymph nodes (x400).

and strong p53 expression was a focal micropapillary SBT with areas of high grade serous papillary carcinoma.

Relation between p16 staining ratio and p53 staining intensity was not found to be statistically significant. Correlation between the staining proportion of two markers was not statistically significant either. The concordance between p 16 and p53 expression rate was calculated as $22 \%$.

Expression of CD24 and EpCAM: CD24 expression was present in 98\% (43/44) of the cases. Expression was membranous (apical or circumferential) and/or cytoplasmic. Staining was patchy in 53\% (23/44) and strong in $77 \%(33 / 44)$ of the cases. All of the cases that showed diffuse staining had also strong staining whereas patchy stained cases were all weak in intensity. Cytoplasmic staining accompanied the apical membranous staining in $40 \%(17 / 44)$ of the cases. Strong, diffuse and circumferential membranous and cytoplasmic staining was detected in the neoplastic cells in the lymph node (Figure 4A and 4B). The neoplastic cells in the microinvasion area showed weak staining. Intensity of EpCAM expression was strong in 97\% $(39 / 40)$ of the cases. EpCAM expression was patchy and circumferential membranous in $57 \%(23 / 40)$ of the cases. Cytoplasmic expression accompanied in $20 \%(8 / 40)$ of the cases. EpCAM expression in the neoplastic cells in the lymph node and area of microinvasion was also cytoplasmic (Figure $5 \mathrm{~A}, \mathrm{~B})$. EpCAM expression loss was noticed in all of the micropapillary cases and no circumferential membranous staining was present. Cytoplasmic expression ratio was high in cases with extraovarian lesions. No statistically significant relation was found between the cytoplasmic expression of $\mathrm{CD} 24$ and EpCAM and between diffuse expression of the same markers. No statistically significant difference was found between EpCAM expression in different tumor types and extraovarian lesions.

Expression of calretinin: Focal, strong, nuclear and cytoplasmic calretinin expression was detected in two micropapillary borderline tumors (Figure 6A,B). No calretinin expression was detected in other cases or in the neoplastic cells in the lymph node and microinvasion areas.
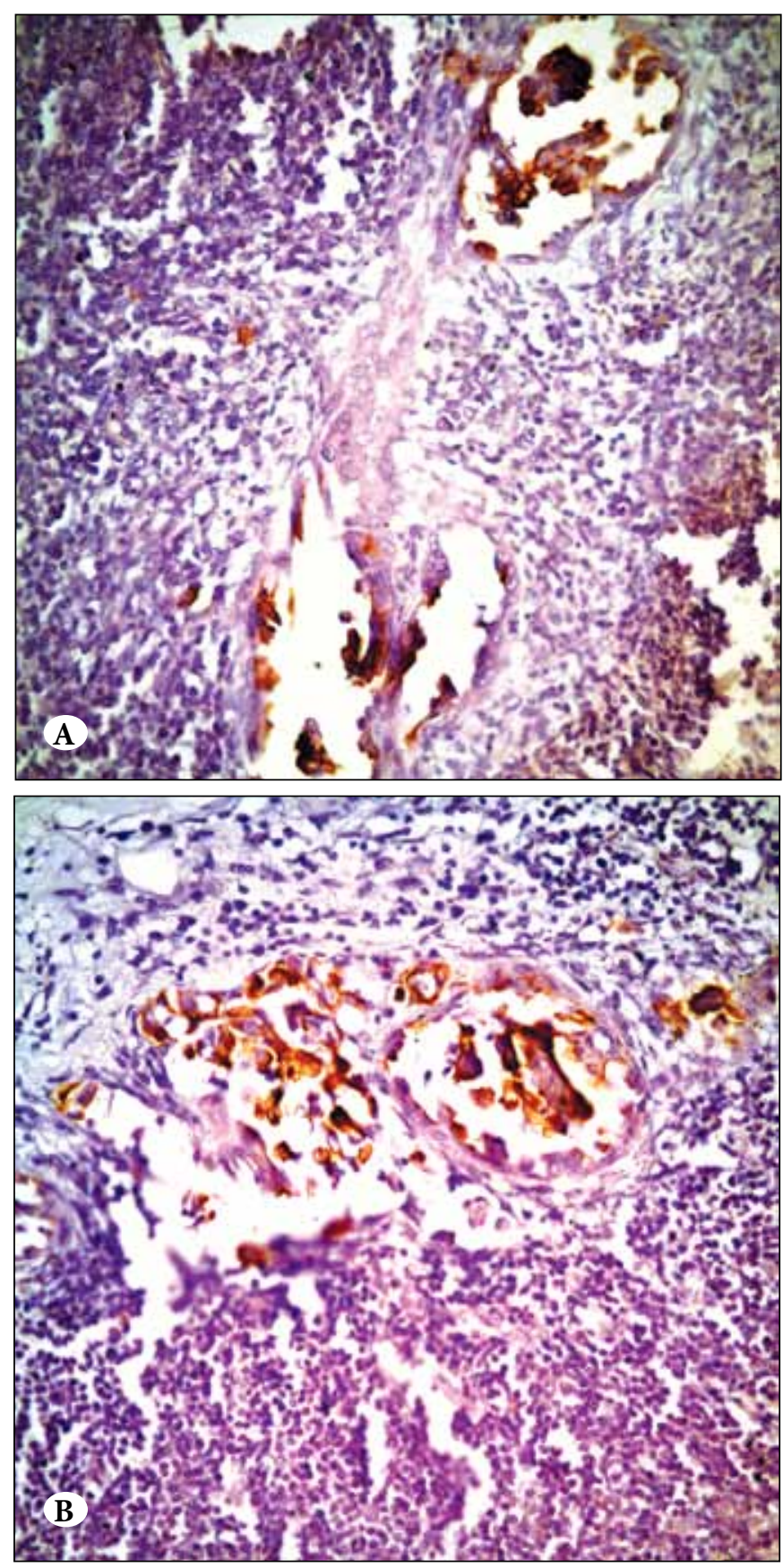

Figure 4A, B: CD24 expression in involved lymph nodes (x400). 


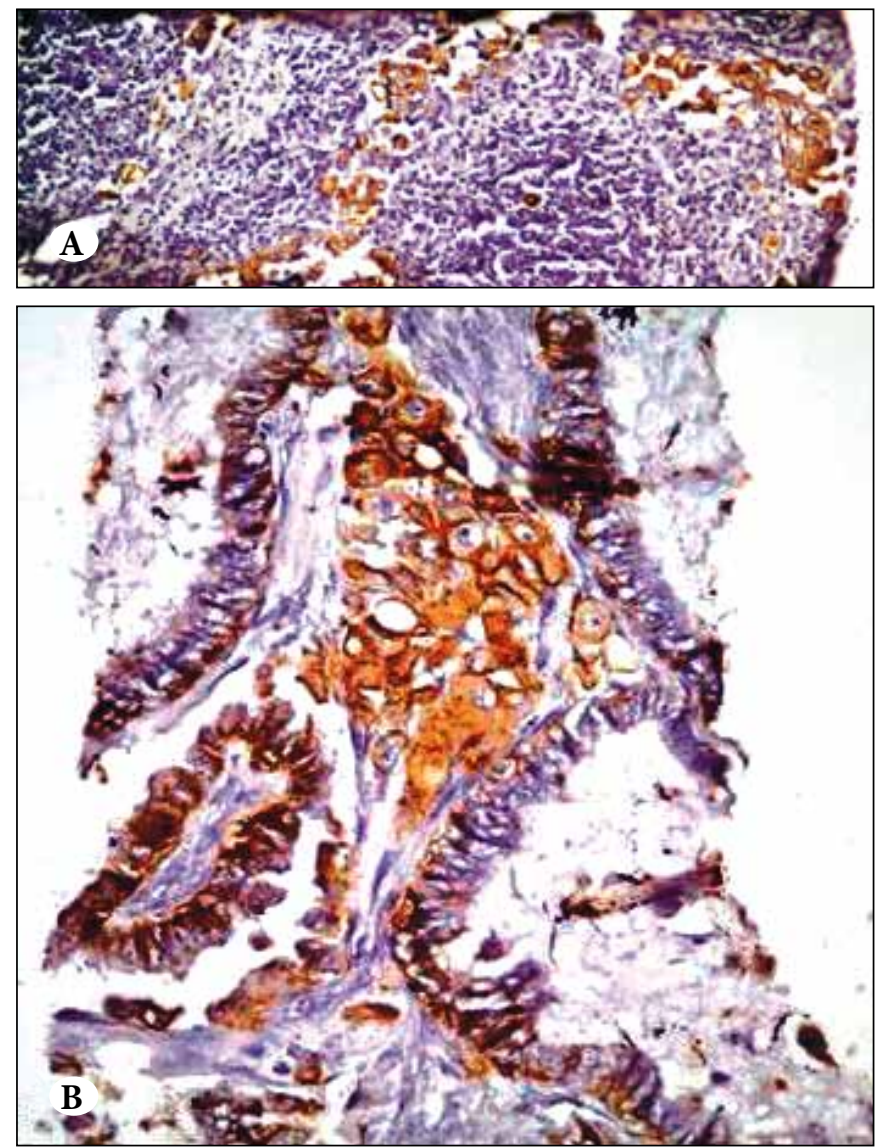

Figure 5: EpCAM expression in (A) involved lymph nodes (x400), and (B) microinvasion areas (x400).

\section{DISCUSSION}

Checkpoints of the cell cycle are investigated in great detail in studies related to tumor progression. p16 and p53, as regulator genes of cell proliferation and apoptosis, are main targets in the chromosomal changes. p53 gene inactivation is the most common defect in ovarian cancer with a $60 \%$ mutation rate in advanced stage ovarian carcinoma whereas immunohistochemical p53 expression in SBTs varies from 0 to $33,3 \%$ (11-21). Ratio of p53 expression in SBTs is reported to be between benign and malignant tumors (15, 22-24).

In our study p53 expression was either absent or scarce ( 0 to $10 \%)$ in $64 \%(28 / 44)$ of the cases. When evaluated according to the percentage of $\mathrm{p} 53$ expressing cells, staining over $50 \%$ was present in only 2 cases (7\%). Additionally, SBTs with wide areas of cystadenoma were p53 negative. In contrast to our findings, Chan et al. reported no detectable p53 expression in borderline tumors (25). This controversy is due to differences in semiquantification of p53 expression. p53 mutation rate is reported higher in SBTs with carcinomatous component when compared
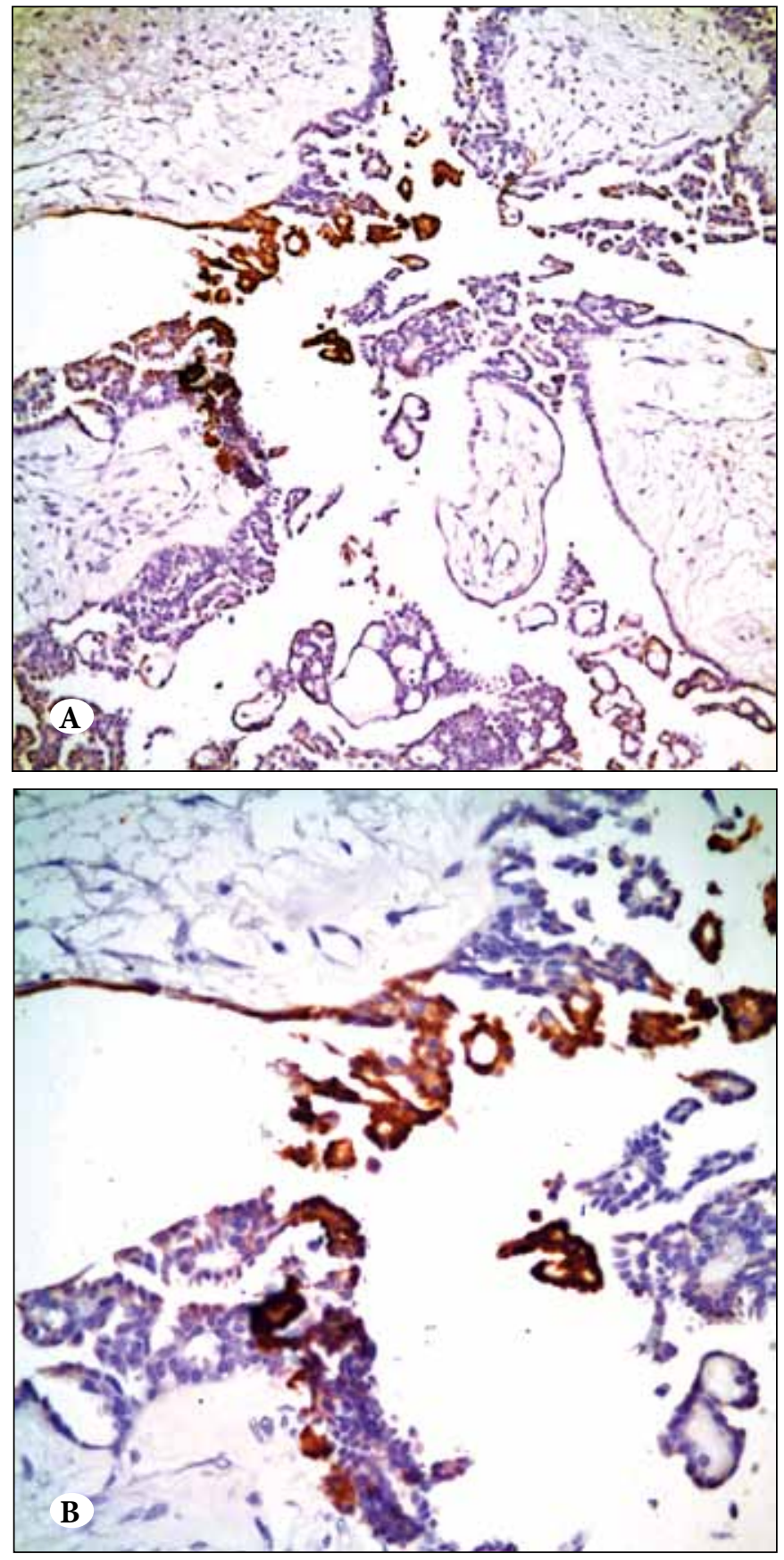

Figure 6: Calretinin expression in micropapillary borderline tumors (A, x200; B, x400).

to conventional SBTs (26). In this study, 53\% of typical borderline tumors had a p53-positive cell percentage of less than $10 \%$. Although the case group is small, p53 positivity was between $10-50 \%$ in $60 \%$ of the microinvasive tumors and over $50 \%$ in low grade serous carcinoma.

Growth control by p53 is intact in low malignant potential tumors and activated p53 limits the cell proliferation in this tumor group. It is proposed that tumors without p53 
mutation can bypass the negative regulating effects of wildtype $\mathrm{p} 53$ using the changes in other growth regulating genes (p16, Rb) (27-28).

Dong et al. have detected no p16 expression in the neoplastic cells of benign ovarian tumors whereas only $11 \%$ of the malignant tumors did not express p16 (29). Supportingly, Fujita et al. proposed that loss of p16 expression is correlated with good prognosis, low grade and low stage (30).

In our study, p16 positivity was present in all of the cases (staining intensity was strong but not diffuse in any of the SBTs) and its expression was over $50 \%$ in $58 \%$ of the cases. O'neill et al. reported p16 expression in less than $50 \%$ of the cells in $72 \%$ of the SBT cases and in more than $50 \%$ of the cells in $92 \%$ of the high grade carcinomas (31). On the contrary, Sui et al. reported that p16 expression was decreased in ovarian carcinomas (32).

In Dong's study epithelial and stromal cells of the nonneoplastic ovary expressed little or no p16 (33). In contrast with the tumor cells, high p16 expression rate in stromal cells is proposed to be related to longer survival (29, 33). In stromal cells of the normal tissue $\mathrm{p} 16$ positivity rate is low as expected, because, there is no p16 expression in cells at rest (34). Stromal-epithelial interactions are important in carcinogenesis; p16 might be preventing the stromal support to the tumor by an antiproliferative function in the stromal cells that are forced to proliferate by the growth factors from the tumor (35). This kind of stromal positivity might suggest that tumor growth is, in part, related to the p16 positivity in the matrix. In our study, the diffuse and strong 16 positivity detected in the stromal cells of all the cases might be related to the good prognosis of SBTs.

Strong nuclear and cytoplasmic p16 expression in all of the cases in this study supports potential role of p16 in serous tumor pathogenesis. p16 expression was diffuse when there was progression to low grade serous carcinoma. It is possible to relate patchy p16 expression in borderline tumors and diffuse p16 staining pattern in higher grade tumors to p16's selection of proliferating cells. The patchy staining pattern of p16 in SBTs may be considered as a sign of the fact that neoplastic cells with different rates of proliferation are present together in these heterogenous tumors. Furthermore, diffuse and strong expression of p16 in advanced stage ovarian carcinomas, may be due to the autonomy they acquired, independent of the cell cycle, as a result of p53 mutation. In relation to this hypothesis, the patchy p16 staining in SBTs and low grade serous carcinomas, which are accepted as sequential lesions, may be because these neoplasia are still under the control of cell cycle mechanisms and despite p16 expression, neoplastic cell proliferation cannot be prevented and progression continues due to the defect at this checkpoint.

Cytoplasmic expression of CD24, which is accepted as a metastasis related cell surface protein, is reported as an independent prognostic factor (36-37). Cytoplasmic expression of CD24 might be reflecting overproduction of CD24 or the disorder in the distribution of CD24 inside the cell or both (38). In neoplasia, the loss of cell polarity is characteristic, whereas, it is conserved in organized normal cells.

We found that the polarized apical localization of CD24 was spared in SBTs. It was also noticed that cytoplasmic CD24 staining in SBTs was accompanied by microinvasion or peritoneal implant. The neoplastic cells in the microinvasion area were examined in only one case and weak CD24 expression was detected. Cytoplasmic expression was detected in $40 \%(2 / 5)$ of the cases, when areas other than the microinvasion areas were evaluated in microinvasive tumors. In low grade carcinoma cases, in nonneoplastic areas, apical membranous expression was detected whereas cytoplasmic expression was present only in the neoplastic areas. These findings are not compatible with the findings of Choi et al., who reported that cytoplasmic positivity in areas other than the microinvasion areas in borderline tumors with multiple microinvasion foci, guided the pathologist to find the microinvasive focus (37). On the other hand, we observed that cases with peritoneal implants had increased cytoplasmic and strong CD24 staining rates (60\% and 80\% respectively). Additionally, circumferential membranous and cytoplasmic CD24 staining detected in the presence of lymph node involvement might be considered as a sign of loss of polarity.

Compared to the diffuse, strong and cytoplasmic CD24 staining detected in high grade serous carcinoma, it can be concluded that the expression pattern of CD24 in SBTs is variable (patchy/cytoplasmic/weak) and change in localization of the expression might be evaluated as a sign of transformation to invasive phenotype.

EpCAM, which functions as an intercellular adhesion molecule, has also been related to metastasis and ovarian tumor differentiation (39). Santin et al. detected its expression rate in serous papillary carcinoma to be 39 times of normal ovarian surface epithelium (40) and Cherchi et al. reported its expression in 50\% of the serous tumors (41). Anti-EpCAM antibody is a therapeutic option in ovarian cancer. Kim et al. also suggested that EpCAM has a role in early phase of tumorigenesis of both borderline and invasive tumors (42). 
In many non-neoplastic epithelial tissue EpCAM is expressed in a basolateral membranous pattern. In our study, EpCAM expression was present in all of the cases with a strong, patchy and membranous pattern (basolateral and/ or circumferential). Its expression was lost in large extent in areas with classical micropapillary morphology whereas stronger, more diffuse and circumferential membranous and/or cytoplasmic staining was present in areas of focal micropapillary morphology. The loss of EpCAM expression might be related to the cellular morphological changes that take place when unciliated cuboidal cells of micropapillary SBT replaces the ciliated columnar cells of typical SBT (43). Loss of EpCAM expression may be considered as a sign of tumor cell dedifferentiation as well (44).

The pattern of EpCAM expression in neoplastic cells in the extraovarian lesions was cytoplasmic instead of membranous. Gosens et al. have also observed the membranous expression of EpCAM to be replaced by cytoplasmic expression in colorectal carcinoma cells, and correlated it with tumor budding, tumor grade, and local recurrence (43). Morphoregulatory activity of EpCAM is different when it is cytoplasmic, compared to the membranous localization, and this change in morphoregulatory activity may result in easier movement and distribution of neoplastic cells (43).

Ovarian surface epithelial cells show both mesothelial and epithelial differentiation and the Müllerian metaplasia of this epithelium is accepted as a step in ovarian carcinoma progression (45-46). Lugli et al. has detected strong calretinin expression in $6,8 \%$ and weak calretinin expression in $38,6 \%$ of ovarian serous carcinomas whereas Drapkin et al. have not detected any calretinin expression in ovarian carcinoma $(47,48)$.

In our study, calretinin was expressed in two micropapillary SBT cases focally and strongly. This observation requires further verification with larger case groups. It might be explained as a result of the resemblance of the unciliated, round nucleated, cuboidal cells lining the micropapilla to the ovarian surface epithelium which has not gone through Müllerian metaplasia and expresses calretinin.

In summary, our findings suggest that changes in immunohistochemical expression pattern of p16, p53, CD24, EpCAM and calretinin accompany different stages of ovarian tumor progression.

\section{ACKNOWLEDGMENTS}

This study is funded by Faculty of Medicine Scientific Research Foundation (Grant numbers 05D11101004,
05D11101005). The authors would like to thank to Orhan Başhan, Çiğdem Karakoç and Arda Günay for technical support and to Lokman Kale for archival assistance.

\section{REFERENCES}

1. Singer G, Kurman RJ, Chang HW, Cho SK, Shih IeM: Diverse tumorigenic pathways in ovarian serous carcinoma. Am J Pathol 2002, 160:1223-1228

2. Vang R, Shih IeM, Kurman RJ: Ovarian low-grade and highgrade serous carcinoma: pathogenesis, clinicopathologic and molecular biologic features, and diagnostic problems. Adv Anat Pathol 2009, 16:267-282

3. Burks $R$, Sherman ME, Kurman RJ: Micropapillary serous carcinoma of the ovary. A distinctive low-grade carcinoma related to serous borderline tumors. Am J Surg Pathol 1996, 20:1319-1330

4. Choi YL, Kim SH, Shin YK, Hong YC, Lee SJ, Kang SY, Ahn $G$ : Cytoplasmic CD24 expression in advanced ovarian serous borderline tumors. Gynecol Oncol 2005, 97:379-386

5. Bellone S, Siegel ER, Cocco E, Cargnelutti M, Silasi DA, Azodi M, Schwartz PE, Rutherford TJ, Pecorelli S, Santin AD: Overexpression of epithelial cell adhesion molecule in primary, metastatic, and recurrent/chemotherapy-resistant epithelial ovarian cancer: implications for epithelial cell adhesion moleculespecific immunotherapy. Int J Gynecol Cancer 2009, 19:860-866

6. Santin AD, Zhan F, Bellone S, Palmieri M, Cane S, Bignotti E, Anfossi S, Gokden M, Dunn D, Roman JJ, O'Brien TJ, Tian E, Cannon MJ, Shaughnessy J Jr, Pecorelli S: Gene expression profiles in primary ovarian serous papillary tumors and normal ovarian epithelium: identification of candidate molecular markers for ovarian cancer diagnosis and therapy. Int J Cancer 2004, 112:14-25

7. Biade S, Marinucci M, Schick J, Roberts D, Workman G, Sage EH, O'Dwyer PJ, Livolsi VA, Johnson SW: Gene expression profiling of human ovarian tumours. Br J Cancer 2006, 95: 1092-1100

8. Rui H, LeBaron MJ: Creating tissue microarrays by cutting-edge matrix assembly. Expert Rev Med Devices 2005, 2:673-680

9. LeBaron M, Crismon HR, Utama FE, Neilson LM, Sultan AS, Johnson KJ, Andersson EC, Rui H: Ultrahigh density microarrays of solid samples. Nat Methods 2005, 2:511-513

10. Scully R: Histological Typing of Ovarian Tumours. World Health Organization International Histological Classification of Tumours. Heidelberg, Springer, 1999

11. Lavarino C, Pilotti S, Oggionni M, Gatti L, Perego P, Bresciani G, Pierotti MA, Scambia G, Ferrandina G, Fagotti A, Mangioni C, Lucchini V, Vecchione F, Bolis G, Scarfone G, Zunino F: p53 gene status and response to platinum/paclitaxel-based chemotherapy in advanced ovarian carcinoma. J Clin Oncol 2000, 18:3936-3945

12. Lee JH, Kang YS, Park SY, Kim BG, Lee ED, Lee KH, Park KB, Kavanagh JJ, Wharton JT: P53 mutation in epithelial ovarian carcinoma and borderline ovarian tumor. Cancer Genet Cytogenet 1995, 85:43-50

13. Van Haaften-Day C, Russell P, Boyer CM, Kerns BJ, Wiener JR, Jensen DN, Bast RC Jr, Hacker NF: Expression of cell regulatory proteins in ovarian borderline tumors. Cancer 1996, 77:20922098 
14. Wen W, Reles A, Runnebaum IB, Sullivan-Halley J, Bernstein L, Jones LA, Felix JC, Kreienberg R, el-Naggar A, Press MF: P53 mutations and expression in ovarian Cancers:correlation with overall survival. Int J Gynecol Pathol 1999, 18:29-41

15. Klemi P, Takahashi S, Joensuu H, Kiilholma P, Narimatsu E, Mori M: Immunohistochemical detection of p53 protein in borderline and malignant serous ovarian tumors. Int J Gynecol Pathol 1994, 13:228-233

16. Kupryjańczyk J, Bell DA, Yandell DW, Scully RE, Thor AD: p53 expression in ovarian borderline tumors and stage I carcinomas. Am J Clin Pathol 1994, 102:671-676

17. Marcelli AR, Demopoulos RI, Goswami S, Mittal KR: Comparison of p53 and MIB1 expression in benign and borderline areas of ovarian serous tumors. Int J Gynecol Pathol 1996, 15:39-44

18. Koshiyama M, Konishi I, Mandai M, Komatsu T, Yamamoto S, Nanbu K, Mori T: Immunohistochemical analysis of p53 protein and $72 \mathrm{kDa}$ heat shock protein (HSP72) expression in ovarian carcinomas. Correlation with clinicopathology and sex steroid receptor status. 1995, 425:603-609

19. Havrilesky L, Darcy M, Hamdan H, Priore RL, Leon J, Bell J, Berchuck A; Gynecologic Oncology Group Study: Prognostic significance of p53 mutation and p53 overexpression in advanced epithelial ovarian cancer: a Gynecologic Oncology Group Study. J Clin Oncol 2003, 21:3814-3825

20. Kupryjanczyk J, Bell DA, Dimeo D, Beauchamp R, Thor AD, Yandell DW: p53 gene analysis of ovarian borderline tumors and stage I carcinomas. Hum Pathol 1995, 26:387-392

21. Hashiguchi Y, Tsuda H, Inoue T, Nishimura S, Suzuki T, Kawamura N: Alteration of cell cycle regulators correlates with survival in epithelial ovarian cancer patients. Hum Pathol 2004 $35: 165-175$

22. Fauvet R, Dufournet C, Poncelet C, Uzan C, Hugol D, Daraï E: Expression of pro-apoptotic (p53, p21, bax, bak and fas) and antiapoptotic (bcl- 2 and bcl-x) proteins in serous versus mucinous borderline ovarian tumours. J Surg Oncol 2005, 92:337-343

23. Zusman I, Gurevich P, Gurevich E, Ben-Hur H: The immune system, apoptosis and apoptosis-related proteins in human ovarian tumors (a review). Int J Oncol 2001, 18:965-972

24. Gershenson D: Contemporary treatment of borderline ovarian tumors. Cancer Invest 1999, 17:206-210

25. Chan WY, Cheung KK, Schorge JO, Huang LW, Welch WR, Bell DA, Berkowitz RS, Mok SC: Bcl-2 and p53 protein expression, apoptosis, and p53 mutation in human epithelial ovarian cancers. Am J Pathol 2000, 156:409-417

26. Schuijer M, Berns, EM: TP53 and ovarian cancer. Hum Mutat 2003, 21:285-291

27. Sarkar S, Jülicher KP, Burger MS, Della Valle V, Larsen CJ, Yeager TR, Grossman TB, Nickells RW, Protzel C, Jarrard DF, Reznikoff CA: Different combinations of genetic/epigenetic alterations inactivate the p53 and pRb pathways in invasive human bladder cancers. Cancer Res 2000, 6:3862-3871

28. Mark I, Jones PA: Presence and location of TP53 mutation determines pattern of CDKN2A/ARF pathway inactivation in bladder cancer. Cancer Res 1998, 58:5348-5353
29. Dong Y, Walsh MD, McGuckin MA, Gabrielli BG, Cummings MC, Wright RG, Hurst T, Khoo SK, Parsons PG: Increased expression of cyclin-dependent kinase inhibitor 2 (CDKN2A) gene product $\mathrm{P} 16 \mathrm{INK} 4 \mathrm{~A}$ in ovarian cancer is associated with progression and unfavourable prognosis. Int J Cancer 1997, 74:57-63

30. Fujita M, Enomoto T, Haba T, Nakashima R, Sasaki M, Yoshino K, Wada H, Buzard GS, Matsuzaki N, Wakasa K, Murata Y: Alteration of p16 and p15 genes in common epithelial ovarian tumors. Int J Cancer 1997, 74:148-155

31. O'Neill CJ, McBride HA, Connolly LE, Deavers MT, Malpica A, McCluggage WG: High-grade ovarian serous carcinoma exhibits significantly higher p16 expression than low-grade serous carcinoma and serous borderline tumour. Histopathology 2007, 50:773-779

32. Sui L, Dong Y, Ohno M, Goto M, Inohara T, Sugimoto K, Tai Y, Hando T, Tokuda M: Inverse expression of Cdk4 and p16 in epithelial ovarian tumors. Gynecol Oncol 2000, 79:230-237

33. Dong Y, Walsh MD, McGuckin MA, Cummings MC, Gabrielli BG, Wright GR, Hurst T, Khoo SK, Parsons PG: Reduced expression of retinoblastoma gene product (pRB) and High expression of $\mathrm{p} 53$ are associated with poor prognosis in ovarian cancer. Int J Cancer (Pred Oncol) 1997, 74:407-415

34. Tam S, Shay JW, Pagano M: Differential expression and cell cycle regulation of the cyclin-dependent kinase 4 inhibitor p14INK4. Cancer Res 1994, 54:5816-5820

35. Harrison RF, Reynolds GM., Rowlands DC: Immunohistochemical evidence for the expression of proliferating cell nuclear antigen (PCNA) by non-proliferating hepatocytes adjacent to metastatic tumours and in inflammatory conditions. J Pathol 1993, 171:115-122

36. Kristiansen G, Denkert C, Schlüns K, Dahl E, Pilarsky C, Hauptmann S: CD24 is expressed in ovarian cancer and is a new independent prognostic marker of patient survival. Am J Pathol 2002, 161:1215-1221

37. Choi YL, Kim SH, Shin YK, Hong YC, Lee SJ, Kang SY, Ahn G: Cytoplasmic CD24 expression in advanced ovarian serous borderline tumors. Gynecol Oncol 2005, 97:379-386

38. Weichert W, Denkert C, Burkhardt M, Gansukh T, Bellach J, Altevogt P, Dietel M, Kristiansen G: Cytoplasmic CD24 expression in colorectal cancer independently correlates with shortened patient survival. Clin Cancer Res 2005, 11:6572-6581

39. Balzar M, Winter MJ, de Boer CJ, Litvinov SV: The biology of the 17-1A antigen(Ep-CAM). J Mol Med 1999, 77:699-712

40. Santin AD, Zhan F, Bellone S, Palmieri M, Cane S, Bignotti E, Anfossi S, Gokden M, Dunn D, Roman JJ, O'Brien TJ, Tian E, Cannon MJ, Shaughnessy J Jr, Pecorelli S: Gene expression profiles in primary ovarian serous papillary tumors and normal ovarian epithelium:identification of candidate molecular markers for ovarian cancer diagnosis and therapy. Int J Cancer 2004, 112:14-25

41. Cherchi PL, Marras V, Capobianco G, Ambrosini G, Piga M, Fadda GM, Dessole S: Immunohistochemical evaluation of a new epithelial antigen, Ber-EP4, in ovarian cancer: preliminary results. Eur J Gynecol Oncol 2001, 22:433-435 
42. Kim JH, Herlyn D, Wong KK, Park DC, Schorge JO, Lu KH, Skates SJ, Cramer DW, Berkowitz RS, Mok SC: Identification of epithelial cell adhesion molecule autoantibody in patients with ovarian cancer. Clin Cancer Res 2003, 9:4782-4791

43. Gosens MJ, van Kempen LC, van de Velde CJ, van Krieken JH, Nagtegaal ID: Loss of membranous Ep-CAM in budding colorectal carcinoma cells. Mod Pathol 2007, 20:221-232

44. Went P, Vasei M, Bubendorf L, Terracciano L, Tornillo L, Riede $U$, Kononen J, Simon R, Sauter G, Baeuerle PA: Frequent highlevel expression of the immunotherapeutic target Ep-CAM in colon, stomach, prostate and lung cancers. Br J Cancer 2006, 94:128-135

45. Papadaki L, Beilby JO: The fine structure of the surface epithelium of the human ovary. J Cell Sci 1971, 8:445-465
46. Blaustein A, Lee $\boldsymbol{H}$ : Surface cells of the ovary and pelvic peritoneum: A histochemical and ultrastructure comparison. Gynecol Oncol 1979, 8:34-43

47. Lugli A, Forster Y, Haas P, Nocito A, Bucher C, Bissig H, Mirlacher M, Storz M, Mihatsch MJ, Sauter G: Calretinin expression in human normal and neoplastic tissues: a tissue microarray analysis on 5233 tissue samples. Hum Pathol 2003, 34:994-1000

48. Drapkin R, Crum CP, Hecht JL: Expression of candidate tumor markers in ovarian carcinoma and benign ovary: Evidence for a link between epithelial phenotype and neoplasia. Hum Pathol 2004, 35:1014-1021 